\title{
"The Forgotten Treasure in the Midst of Wants": An Assessment of Igbariam Farm Settlement Scheme in Eastern Nigeria, 1961 - 1979
}

\author{
Isiani Mathias Chukwudi \\ Department of History and International Studies \\ University of Nigeria, Nsukka \\ $+2347067660853$ \\ mathias.isiani@unn.edu.ng \\ Uche Augustine, Igwe \\ Department of History and International Studies \\ Nnamdi Azikiwe University, Awka \\ $+2347039411555$ \\ au.igwe@unizik.edu.ng
}

DOI: 10.29322/IJSRP.10.02.2020.p9872

http://dx.doi.org/10.29322/IJSRP.10.02.2020.p9872

\begin{abstract}
The 1946 constitution of Nigeria was the first to regionalize political power in Nigeria, followed by the 1951 and 1954 constitutions; the later deepened the forms and shape of regional government in Nigeria. It was also the constitution that systematized the revenue system thus making derivative principle the cardinal revenue allocation format for the three regions. This economic principle spurred the colonial government to modify her agricultural policies as well as the regional governments of Nigeria at independence for a 'sustainable and reliable economy.' The Eastern regional government under Dr. M.I. Okpara inspired by the Israeli Moshavim Farm Settlement Scheme, pioneered the establishment of farm settlements in Abak, Erei, Boki, Igbariam, Ohaji, Ulonna and Uzo-Uwani areas of the region. These farm settlements were to stem rural-urban migrations, generate revenue, curb social vices and create employment opportunities. Sadly, the huge expectations its establishment raised were dashed following the horrendous Nigeria-Biafra Civil War and official neglect after the war as a result of the oil bloom of the 1970s and the systematic and total reliance on oil by successive governments. There appears to be lack of enthusiasm among scholars', leaders and governments in the Region to push for the revival of the Farm Settlements across the Region and the rest of Nigeria. Ironically, scholars have neglected this area of scholarship over time thus making extant literature scarce. This work hopes to fill this obvious gap in historical knowledge by reappraising the achievements and challenges of Igbariam Farm Settlement between 1961-1979. Using archival sources for the interpretation of the study area, newspapers, journals, personal diaries and other extant secondary sources, the research suggests a reappraisal of Igbariam Farm Settlement Scheme in the defunct Eastern Nigeria. In this regard, qualitative and quantitative methodology will be used in the course of the interpretation of results. The theory of individual/opportunity nexus and population theory will be employed to ascertain which of the two will be dominant in the study as regards to the present economic situation in the country.
\end{abstract}

Keywords: Igbariam, Agriculture, Economy, Eastern Nigeria and Farm Settlement.

\section{Introduction}

The Nigeria-Biafra war (1967-1970) was fought, won and lost. However, the echoes still resound around and continued to generate various perceptions and energies of discourse that further interrogates the essence of war from the ambience of history and socio-political and economic assessment. More than fifty years after the civil war, pockets of news about the war had risen and sank deep into the memories of children born five decades after the war. The devastating nature of the war had cut up the society with emergence of freedom fighters and "policemen" of each region consciously securing their community and seeking for social justice after the war. To some of these groups, the perpetrators of the war had been applauded overtime and the defeated society suffers in penury with little or no regard for rehabilitations after the war. One wonders why this war had had a lasting impact on society as a 
whole and why its causes have not been addressed. This is particularly true of women and young girls that was sexually harrassed during the war, displacement of individuals, starvation and looting of homes and farmlands in this affected society. In Igbo society with special regards to the present Southeastern Nigeria the various marketplaces, houses and churches were pillaged and demolished. ${ }^{1}$ The society lost their loved ones, children lost parents, wives lost their husbands and other relations. Those who perished in the war were breadwinners and their off springs endured excruciating hardship thereafter. Both public and private buildings are reduced to rubble in the course of the Nigeria-Biafra war. ${ }^{2}$ To destroy these constructions was easy for the Nigerian armies but to rebuild seemed to be difficult as the entire Igbo society faced humiliation and rejection from the federal government since 1970. The drastic effects of wars in a society shook the survivors both physical and psychological as well "had deleterious effect on the environment and civil population."

Before the civil war, the Igbo society had attained a great level in different sections of life. These sectors of development include education, infrastructures, agriculture politically advanced. The 30 months Nigerian-Biafran civil war interpreted the ongoing advancement of these sectors that by the end of the civil war in January 1970, the entire Igbo society had been destroyed and brought into desolation. Obi-Ani noted that at the end of the civil war in January 1970, most of the achievements had been shattered in the war. $^{4}$

To further strengthen the effect of the civil war, Obi-Ani further noted that:

The war had uprooted much of the economic infrastructures of Igboland, claimed the lives of the cream of the society and disabled many. Confusion, a feeling of insecurity and despair prevailed among the Igbo. All the Igboland was studded with innumerable road blocks mounted by the victorious Nigeria Army. ${ }^{5}$

The Igbo society was challenged with harsh conditions after the war. Igbo farmers, small traders, artisans and clerks worked all hours of the day and half the night, building up a sort of life again. ${ }^{6}$ The war was devastating that the entire place after the war was like a grave yard smelling dead human flesh with smokes over the community for a period of months. ${ }^{7}$ Noting the war crime in Igboland, Obi-Ani documented that:

In a war situation, it is usually easy to destroy than to rebuild. Even reconstruction can never bring back what had been damaged. Many magnificent edifices are lost forever...The ravages of the war lingered on for years in various hues and guises such as social stigma, economic pauperization of the people, breakdown of communal cohesion, in political limbo and women liberation and other issues. ${ }^{8}$

The Nigeria civil war to Korieh had the most important long-term effect on agriculture among the Igbo. To him:

The civil war ruined the Eastern Regional government agricultural programs and destroyed the optimism of the early 1960s. With the outbreak of the Nigerian civil war in 1967; palm oil exports, the major cash crop for the Igbo, declined to 16,000 tons, compared with 165,000 tons in 1961. Palm kernel export, a major source of income for women, also declined to 162,000 tons in 1967 as against 411,000 tons in $1961 .{ }^{9}$

Virtually all the farm lands in Igboland were destroyed during the civil war period. Farm settlements, the economic reservoir of the Eastern Nigeria was looted and destroyed by the Nigerian soldiers who saw the farm settlement areas as the food basket of the region and as well achieve the victimization food policy of 'Gowon -Awolowo.' The war left the ordinary farmers traumatized that on return to the farm settlement areas, many broke into tears and suffered heart attacks following the bombed farm crops and farm 
implements. ${ }^{10}$ The Igbariam farm settlement witnessed the 'highest destruction of crops, stealing of farm implements and storage produce. ${ }^{11}$

The end of the civil war in 1970 and the victory of Nigerian government over the Biafrans (Igbo) stretched the 'merciful' hands of reconstructing the dilapidated structures, rehabilitating the agricultural and other economic affected sectors which was levelled as a result of bombs and shelling and to further strengthen the country's unity through reintegrating the seceding Biafrans back to Nigeria as 'one country.' The government of Gowon through his public 'no victory no vanquish' started applying the his widely 3Rs (Reconstruction, Reconciliation and Rehabilitation). This policy became a charade to deceive the international community, the frenzy for survival by hook or crook emerged among the Igbo. ${ }^{12}$ The need to halt the deteriorating social and economic conditions in Igboland became the so-called main desire of Gowon administration. In articulating Gowon's reconstruction policy, Obi-Ani documented Gowon's broadcast to the nation on January 15, 1970:

There is an urgent task to be done. The Federal Government has mounted a massive relief operation to alleviate the suffering of the people in the newly liberated areas. We are mobilizing adequate resources from the Federal government to provide food, shelter and medicines for the affected population. Rehabilitation and reconstruction will follow simultaneously to restore electricity, water, transport, and communications. We must as a matter of urgency, resettle farms and reopen factories to ensure that normal economic life is resumed by everyone as soon as possible. ${ }^{13}$

Nevertheless, how General Gowon revived the farm settlements through the Federal government economic mission support to the East Central States on agricultural programmes and the new agricultural programmes between 1970 - 1979 are the thrust of this paper.

\section{Federal Government Economic Mission}

All the agricultural sector was abandoned during the Nigerian-Biafran civil war. Particularly the nascent plantations and farm settlements in all the defunct Eastern Nigeria was jettisoned. The government services on the farm settlements and plantations which had just been cleared for cultivation, or even at their early stages of crop maturation, became deserted as they were susceptible to air raids and strategically attacked by the Nigerian troops. ${ }^{14}$ Thus, after the civil war, the Gowon administration proclaimed 'no victor no vanquish" saga in order to attract the attention of the international community of peace making in Nigeria. This pronouncement would integrate the ravaged Igbo community as well as other affected areas in Nigeria back to one statehood. In reconstructing Nigeria, the Gowon administration also took into consideration re-integration and rehabilitation of affected social and economic sectors. In the defunct Eastern Nigeria, the Federal government of Nigeria appointed Mr. Ukpabi Asika as an administrator of East Central State. He would supervise the reconstruction of the different sectors affected by the war. This "Reconstruction" after the thirty months civil war according to Obi-Ani could be viewed from two contrasting perspectives - positive and negative. To him, in the positive perspective, reconstruction is seen as an attempt to integrate the Igbo people into the Nigerian family after their unsuccessful attempt at statehood. From the negative angle, reconstruction can be construed to mean a systematic attempt by the victorious Federal Government to weaken the position of the Igbo in Nigeria so that it would be very difficult, if not impossible for them to become "troublesome" in the future. ${ }^{15}$ The 3 Rs of Gowon would be used to justify this assertion in the federal government agricultural mission support on the Eastern Nigeria after the civil war.

As indicated earlier in the preceding chapters, the economy of the Igbo people was advanced before the war. Agriculture, one of the economic outputs of the society was ruined after the civil war. The war had forced out many farmers from their farms. Many of 
International Journal of Scientific and Research Publications, Volume 10, Issue 2, February 2020

these farmers abandoned their crops in the farms as they fled from the theatres of the war. ${ }^{16}$ Battered were her industries and economic infrastructures in both public and private sectors ${ }^{17}$; the entire farm storage, crops and farm implements in each Igbo society was demolished, destroyed and burnt down by the Nigerian armies. To rehabilitate these economic sectors especially the agricultural sector which the farm settlement is a part became a daunting task for the Federal government, State government and peasant farmers. ${ }^{18}$

The East Central State under Mr. Ukapbi Asika opined laudable objectives for reviving the agricultural sector as well as reconstructing the demolished agricultural farmlands. In regards to the farm settlements, the government of East Central State had before the outbreak of the Nigeria-Biafra civil war tagged the farm settlement as a capital-intensive project and not labour intensive. Concurring with the general perspective of the farm settlement before the war, Dr. Wariboko West, an agricultural economist, had claimed in 1965, that his studies of the Uzo-Uwani farm settlement had revealed "a colossal waste of public funds in a venture that had completely failed." He added that the settlement had been able to produce only a few bags of oranges and a couple of dozens of eggs "for distribution to permanent secretaries and ministers." 19 None of these bodies both in federal and state government investigated the challenges facing the farm settlement as against their sister Israeli Moshav. Consequently, at the end of the civil war, the scheme was abrogated by an Executive Council conclusion No. (72) of April 20, 1972. ${ }^{20}$

In abrogating the farm settlement and for a quick rehabilitation of the agricultural system in East Central State, the committee set up by the administrator suggested that the farm settlements should be converted to community and small holders' scheme. Each of the farm settlement which had earlier belonged to each community before their contract with the state government would have to be reverted. Farmers that wish to be part of this programme would reapply for recruitment in the host communities' farmlands. Selection of these farmers were based on the selection criteria. 


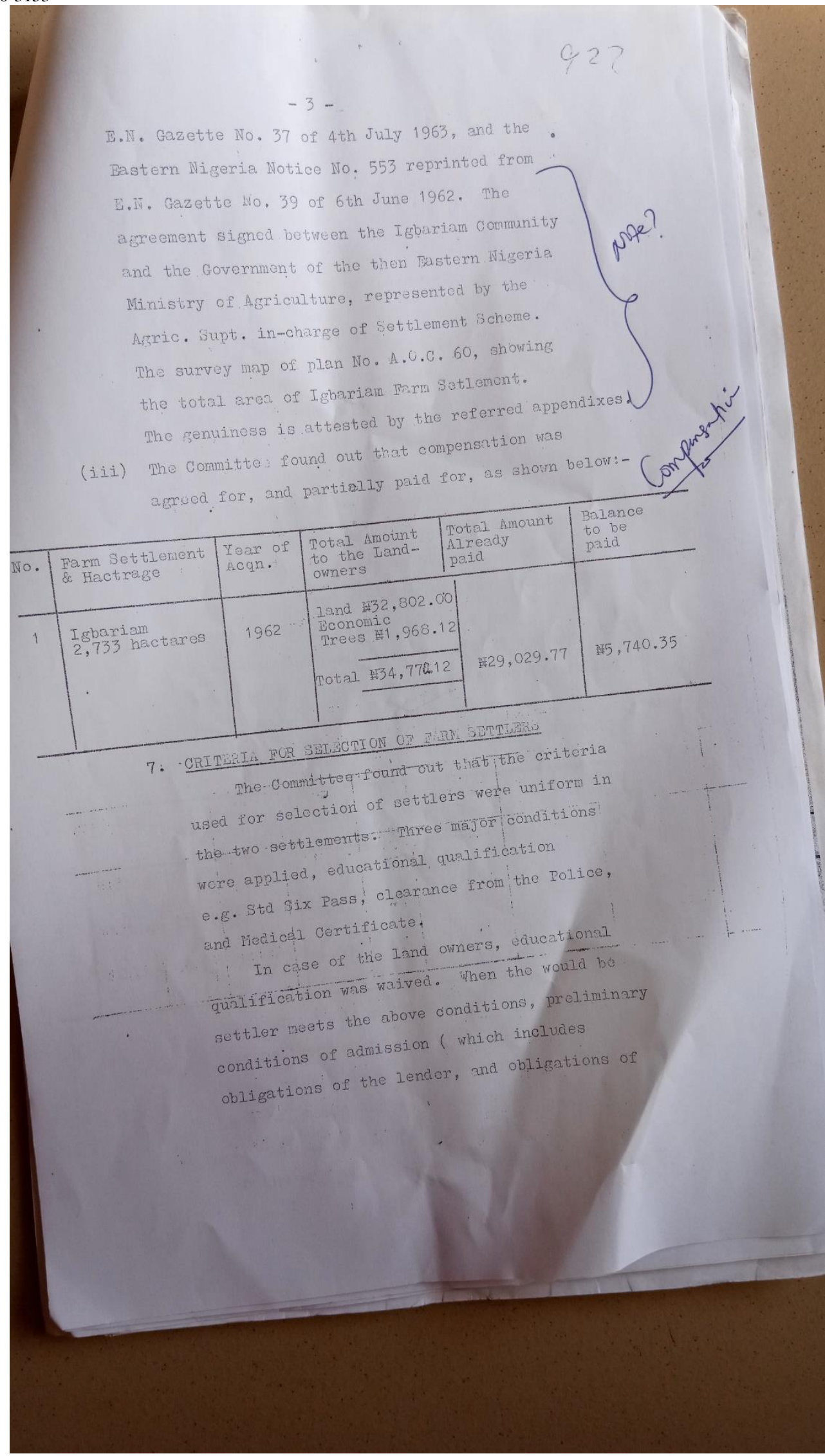




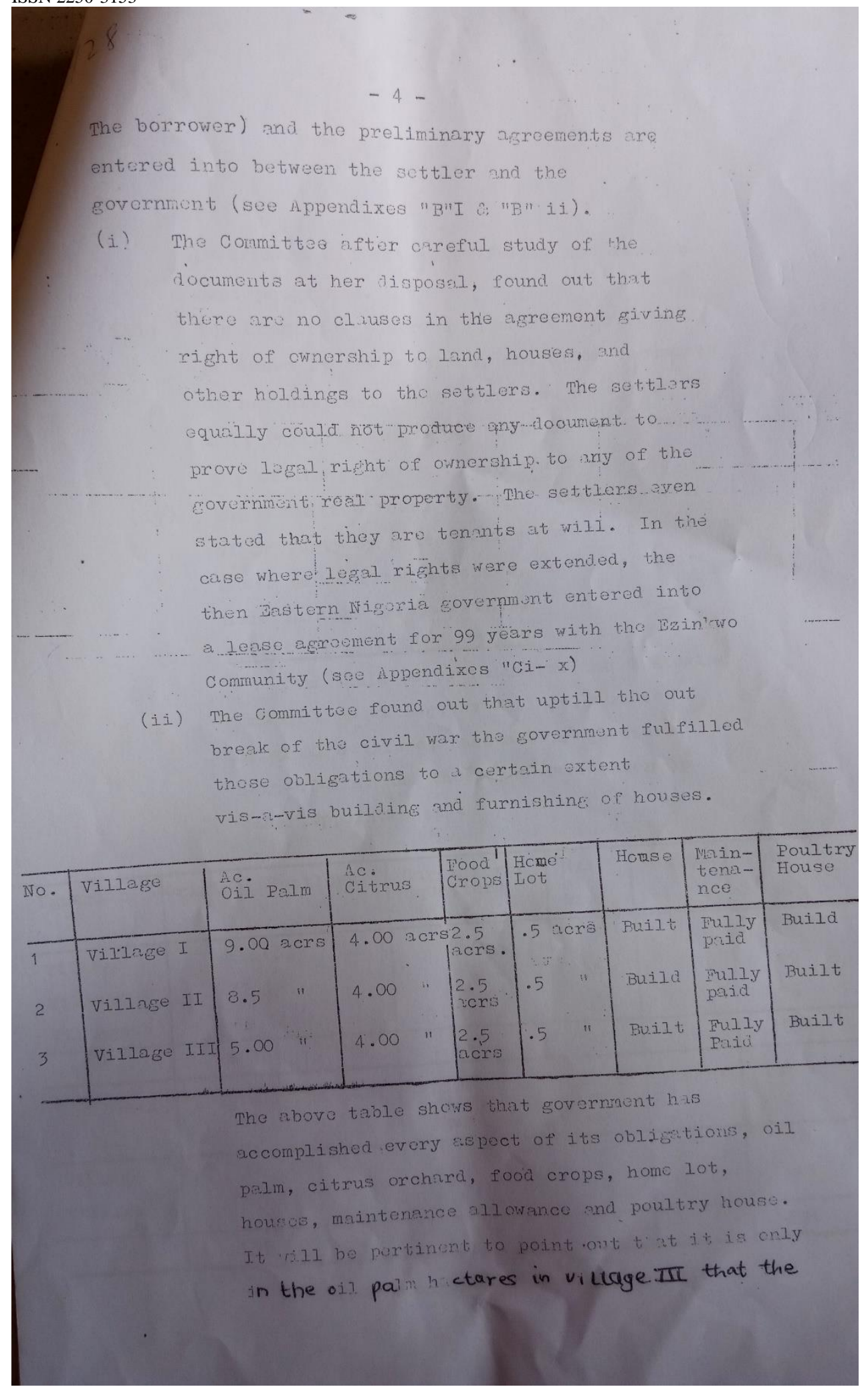

Criteria for Selection of Farm Settlers - Intelligent Report, Farm Settlement (Author, 2019)

From the memo above, the initial settlers were recognized by the committee in the so-called reconstruction programme of Gowon's administration. The committee had suggested they go back to their home town and start a new life. In settling, the initial settlers in the farm settlements, the committee further suggested that: 
The pre-requisite for any of these options is Government's legal abrogation of original farm settlement agreements, re-acquisition of the entire 2,733 ha. And paying off all genuine settler/caretaker claimants' equitable compensation to erase the current messy situation and embark on a fresh start. ${ }^{21}$

Another committee suggested that the original settlers in each farm settlement should be offered two option regarding the rehabilitation of the farm settlements into community farms. They argued that some of the settlers after the civil war moved into another trade rather than farming. To them, the settlers were to be offered the option of:

a. $\quad$ Returning to farming and being allowed to return their holding

Or

b. $\quad$ Continuing with their new non-farming trades and being evicted from the farm; no compensation are contemplated as the settlers having changed to non-farming trades, may be regarded as having broken their contract; however, as Government's decision to abrogate the scheme may have helped in influencing the change, the settlers should not be required to refund the $\$ 5,000.00$ ( $£ 2,500.00$ ) development loan paid to them between 1962 and $1963 .^{22}$

In conclusion, these measures to the committee if applied would go a long way in reviving the economy of the Igbo community.

The Igbariam farm settlement in this regard was the only farm settlement that was not selected for conversion into community farms or small holders' farms neither was the settlers called for compensation. It was with this regard that among the farm settlements in Eastern Nigeria only the Igbariam farm settlement was situated outside the community. In a draft Exco memo on farm settlement versus community farms, Nwafor the Permanent Secretary, Ministry of Health described that:

In respect of the fate of Igbariam Farm Settlement which the Memorandum recommends for community farms, it is doubtful whether this will be practicable for the reason that the farm settlement is not very close to the Igbariam community to be used in the way and manner anticipated in the Memorandum. ${ }^{23}$

It further documented that:

... Igbariam Farm Settlement should be reserved as a Government Farm and be apportioned to the College of Agriculture and the remainder converted into small holders scheme as is practiced in Uzo-Uwani Farm Settlement ... Reallocating the farm settlement to Igbariam Community will be retrogressive because the land was acquired from Igbariam people by Government under a contract agreement involving payment of compensation to the people which might have been completed by now. ${ }^{24}$

How good this objective sounds yet the policy was suspended in limbo and never was recalled.

Another laudable objective of the administration in reviving the farm settlement was setting up of agricultural institutes. In Igbariam farm settlement, the federal and state government established College of Agriculture, the Root Crops Research Institute and the Cereal Research Institute. These institute to the committee was as a result of lack of maintenance and exploitation of oil palm and citrus plantations during the farm settlement period. The committee examined the failure of Igbariam farm settlement as a result of poor managerial output and peasants' lackadaisical attitude towards the project. They argued that many settlers saw the farm settlement as an assistance to government and not as hobby. Many regarded the farm settlement as a civil servant service of thirty-five years. On the other hand, the farmers in Igbariam saw these institutes as intruders to their sweat and not for reconstruction. These settlers fought with these personnel in Igbariam averring that the "intruders dictated what will happen in the nucleus rather than rehabilitating the affected areas in the farm. ${ }^{.25}$ C.U. Osaekwe further noted that: 
These institutes were good at first but their subsequent actions to the settlers threw the settlement into disarray... they never came to the farm settlement for proper management but for exploitation of our seasoned sufferings before the civil war... we have no other option than to fight them back. ${ }^{26}$

To further capture the reason for the settlers' revolt against these institutes in Igbariam farm settlement, Okoye noted that:

...after the war, the government effort to revive the settlement was futile; the settlers were disregarded as the government never asked of their well-being and rehabilitation of the nucleus... the institutes that came around 1972 was a threat to the settlement. ${ }^{27}$

The awareness for the reduction of mass unemployment, starvation and food scarcity through agricultural 1970 rehabilitation policy ushered in the four-year federal government Development Plan (1970-1974) in Nigeria. The four-year Development Plan would enable the farmers with loans, new farm implements and distribution of seedlings to all the affected areas during the civil war period. Thus, Obi-Ani asserting the features for the Development Plan after the war opined that:

The East Central State Government also planned to intensify agricultural production of supervised agricultural credit loan scheme, fertilizer promotion programme, veterinary field services, seed distribution and multiplication scheme, tractor-hiring unit, extension services, animal feed production and distribution and tree crops development scheme. ${ }^{28}$

Asika's committee on the four-year Development and Reconstruction Plan, 1970-1974 reported that the plan if implemented will boost the economy of Nigeria and revive the civil war affected areas. They reported that:

The project (Development Plan) has two aspects, namely: Intensive Food Crops Production Scheme and Seed Multiplication Scheme... The intensive food crops production scheme would include these objectives:

a. $\quad$ To organize farmers effectively to produce certain staple food crops on a large scale for feeding the teeming population of the East Central State.

b. To intensify Government Assistance, including the provision of necessary incentives to farmers as a means of bringing about the development of larger sized food crops farms.

c. To help in resuscitating the agricultural economy of the state which was badly devastated by the Nigeria civil war.

d. To provide opportunities for gainful employment for the rural population and thus reduce the present influx to the towns and the unemployment problems.

e. To help bring about the much desired change from subsistence to commercial farming, provide opportunities for organized marketing of surplus food products... ${ }^{29}$

Furthermore, the Seed Multiplication Scheme, its objectives include:

a. To acquire improved and high yielding breeder seeds for good quality from Research Institutions.

b. To multiply these improved planting materials for distribution to farmers to support the intensive Food Crop Production Scheme.

c. To select dependable farmers and cooperative producer association and train them as Approved Seed Growers

d. To train staff of the ministry to grow and handle pure seeds in Government controlled seed plots and also to supervise, inspect and certify seed plots of approved growers.

e. To cooperate with research institutions in carrying out necessary field observations on the seed released for multiplication. ${ }^{30}$ 
International Journal of Scientific and Research Publications, Volume 10, Issue 2, February 2020

The aim of the government was to solve the problem of food scarcity as noted above, but this plan had appeared to be fruitless because the federal and state government could not match their policies with actions. The agricultural credit loans of $£ 200,000^{31}$ annually and 10 million $^{32}$ free were observed to be in paper and media receiving applauds from the international community. The allocations for these loans was unequally distributed to the so-called affected areas of civil war. The Igbo society was observed to have received less percentage of the loans than the northern Nigeria where the civil war was not experienced as shown below. The loan was not released until the details of food production project of each state has been submitted to the Federal Ministry of Agriculture and National Resources. ${ }^{33}$ 
STATES SHARE OF 110 MTLIION FEDERAL IOAN FOR FOOD PRODTCTION

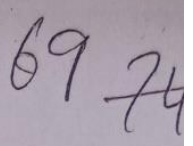
FORIULA: $70 \%$ POPULATION, $30 \%$ EQUAL

\begin{tabular}{|c|c|c|c|c|c|}
\hline STATE & $70 \%$ & & $30 \%$ & TOTAL & \\
\hline WEST & E1190,000 & + & $\$ 250,000=$ & $=\mathbb{N} 1440,000$ & \\
\hline IOORTH-EAST & 959,000 & + & $250,000=$ & $=1209,000$ & \\
\hline KLINO & 714,000 & + & $250,000=$ & 964,000 & \\
\hline NOFIH-WEST & 707,000 & + & $250,000=$ & 957,000 & \\
\hline NORTH-CENTRAL & 567,000 & + & $250,000=$ & 817,000 & \\
\hline BENUE-PLATEAU & 504,000 & + & $250,000=$ & 754,000 & \\
\hline IWARA & 308,000 & + & $250,000=$ & 558,000 & \\
\hline WAST-CENTRAL & 917,000 & + & $250,000=$ & $=1,167,000$ & $x$ \\
\hline SOUTE-EAST & 448,000 & + & $250,000=$ & 698,000 & \\
\hline RIVERS & 189,000 & + & $250,000=$ & $4.39,000$ & \\
\hline MID-WEST & 322,000 & + & $250,000=$ & 572,000 & \\
\hline Li:GOS & 175,000 & + & $250,000=$ & 425,000 & \\
\hline MOTAL & $\$ 7,000,000$ & + & $\mathbb{W}_{3}, 000,000=1$ & $=\$ 10,000,000$ & \\
\hline
\end{tabular}


From the attachment, it would be observed that even as the Eastern Nigeria was devastated and destroyed during the civil war, the reconciliation and reconstruction formula could divide the loan based on "population and land mass." The South-East, East Central and Rivers in the defunct Eastern Nigeria received little than the other regions. The food production details sent by the East Central government to the federal ministry of Nigeria as requested by the administration did not receive response till date as shown in the minutes below.

This agricultural loan and government grant to agriculture did not get to Igbariam farm settlement. Most of the settlers denied the involvement of government into the nucleus after the war let alone rehabilitating the area with credit loan. To Achumi,

We only heard about the government grant in Gowon's 3Rs policy... none came to the farm settlement till date. Whatever we heard about the grant was with the ministry till date. $^{34}$

Treading in the same line, A. Oraukwu noted that:

The post-war agricultural grant was in television, radio and newspapers. The settlers did not partake in the so-called agricultural grant. We wrote over 200 letters for the grant to come to the farm settlement but none of these letters were responded to. The grant was a ghost in human flesh. ${ }^{35}$

In contrast with some of the observations of settlers in Igbariam, Okafor the Chairman Village 3 in Igbariam farm settlement asserted that:

During the development plan policy in Nigeria, the MANR brought $£ 500$ to the settlement in 1972. The $£ 500$ was alleged to be shared to all the settlers in Igbariam strictly for the cultivation of yams. This $£ 500$ was to be returned after two years. Till date, they never came for the returns. ${ }^{36}$

From the both contrasting analyses above, though Okafor opined that the settlement receive $£ 500$ against the majority of other settlers that contradicts this grant; one could wonder how $£ 500$ pounds would be shared among 480 settlers in the four villages. If truly, the chairman received $£ 500$ and it would be used to assist the farmers in the Igbariam farm settlement, why were the settlers forced to cultivate only yams which was against citrus plants and oil palm that the ecological variation was known for before the civil war. As Njoku rightly said "whether the farm settlers received the $£ 500$ or not, the reconstruction grant never got to any settlers... it was all in air and was shared by the federal and state ministers." ${ }^{37}$

There is no doubt that there was no attempt to reconstruct the defunct Eastern Nigeria economy after the civil war. The 3Rs was a sham on Igbo socio-economic organization as every citizen received $£ 20$ irrespective of any amount submitted to federal government treasury. The rehabilitation and reconstruction scheme of Gowon was in paper and hailed by the international community with little attention to his home country. To him Nigeria's problem is not money but how to spend it. ${ }^{38}$ These were squarely to bring down the aged agricultural and economic system of the Igbo society. The government saw agriculture as a waste of resources having been moved with the rise of oil boom and its output. Not much happened to the farm settlements in terms of care. M.I. Okpara's 'baby' was bound to suffer devastating government neglect ${ }^{39}$ as it was tagged "a total waste of government fund' for petro dollars. The fortunes of agriculture have continued to dwindle in Igboland and indeed in other parts of the country. The ordinary Igbo man, even the settlers whose livelihood depended on what they can produce in their farms have continued to exert themselves towards increased few productions in Igboland; ${ }^{40}$ others migrate to major cities in search of oil wells and 'national cake' which have recently led to challenges such as inadequate housing, hospital and traffic in urban areas in Nigeria. By 1976, most of all the farm settlement 
schemes had completely been devastated ${ }^{41}$; each government till date has pronounced one agricultural programme or the other in other to revive the economy. Yet the system is still underdeveloped and the nation still suffers food insecurity and heavy importation of finished food items from both African and European countries.

\section{Post-Civil War Agricultural Policies: A Survey}

The oil boom of 1970s shifted the attention of the Federal and State government from agricultural sector to oil sector. However, the post-civil reconstruction and oil boom only promoted agricultural programmes from different successive governments. The sub-theme will focus on the agricultural programmes and policies in Nigeria between 1970-1979 and how it has affected the Eastern Nigeria having abrogated the farm settlement schemes.

\section{The National Accelerated Food Production Programme (NAFPP)}

National Accelerated Food Production Programme (NAFPP)was an agricultural program initiated by the government of Yakubu Gowon. The focus of the programme was to train farmers with good technical farm implements which would boost the production of targeted specific crops namely cassava, maize, rice, sorghum, millet and wheat. This training could be done through three distinctive components; research, extension services and agro-service. The research component was aimed at producing minikits for use by farmers. Through extension services, the products of research were to be made available to farmers. The agro-service segment of the program aimed at making agricultural inputs available to farmers timely and adequately and at providing outlets for marketing their produce. ${ }^{42}$ The programme will further distribute farm crops to different parts of the country in order to solve the problem of good farm technical implements, food scarcity and inadequate farmers production in Nigeria. To Njoku, the main of the programme was to vastly 'raise farmers' productivity and living standard via an innovative combination of research and technological improvement, extension and agro-service delivery. ${ }^{43}$

As laudable this objective was in tackling the food challenge in Nigeria, yet the programme was more of a paper tiger than it was seen in the society. in 1977-1978, for instance, only 37\% of the budget allocation of 18.7 million was released, and in $1979-$ 1980 , only $48.9 \%$ of $\$ 28$ million allocated was released. ${ }^{44}$ Other lapses identified by Iwuchukwu and Igbokwe on the programme was:

\footnotetext{
a. Farmers who could not form co-operative were likely to be left out in the programme since the programme relied on disbursement of credits and farm inputs through co-operative societies.

b. Demonstration trials were done on some selected farmers' plots by the research and extension personnel which did not give a true/good representation of the outcome of the technology or programme. ${ }^{45}$
}

\section{The Agricultural Development Programme (ADPs)}

ADPs was established in 1974 in Funtna, Gusau and Gombe but between 1975 and 1989 it had spread to all the nineteen states in Nigeria. The objective of the programme is to increase food crop production through the small-scale farmers in all parts of the country. Through the small-scale farmers, the scheme would approach agriculture and rural development through "collaborative efforts and tripartite arrangement of the Federal Government, State Government and World Bank." ${ }^{\prime 6}$ It would as well raise the productivity, the income and living standard of the small-scale farmers through a package of measures which included the provision of improved seeds, fertilizers, pesticides, credit facilities on easy terms and infrastructural facilities such as access roads, water supply 
and health care. ${ }^{47}$ Through the programme, the government would assist the small-scale farmers with loans and credits grants from the world bank and inform the government on the necessary items, implements and seedling necessarily for food advancement in the country.

Though the ADPs had a wider view of incorporating the small-scale farmers in the country to benefit from the scheme but the programme have had its critics as majority of these small-scale farmers rarely benefitted from the loans. The programme excluded the poor from access to productive resources and redistributed the assets and incomes to the rich. ${ }^{48}$

Treading in the same line, Njoku further observed that:

...the programs have proved too hugely expensive for the returns. By 1981, for instance, the first three projects had gulped $\$ 90.2$ million at an average expenditure of $\$ 678$ on a farmer. $^{49}$

The scheme neglected the farmers in the rural areas as it was preoccupied with the bourgeoises and rich government beneficiaries such as retired army general that saw the loan attractive and agriculture "an occupation for the rich." The scheme would be summarized with the expression of "local involvement is at the level of receiving and obeying orders from the expatriates. ${ }^{50}$

\section{River Basin Development Projects (RBDP)}

The programme was stablished under the Decree 25 of 1976 military edicts to promote agricultural products and economic potentials of states within the riverline areas in Nigeria. during this period, eleven RBDAs were created with government mandate of building huge dams, massive irrigation infrastructure, the use of land cleansing equipment, and application of modern agricultural inputs, including fertilizers, herbicides and insecticides. ${ }^{51}$ This programme was essentially promulgated to assist irrigation in the northern Nigeria that had faced low rainfall and arid ecological variations. Through these agricultural projects in these areas, the government created few economic advanced projects such as dan projects, massive vegetables production and feeder roads.

As good as the programme sounds, it also faced challenges such as huge cost of constructing dams and poor growth of food crops from these areas. Substantial public funds were wasted to streamline sizes and functions of RBDPs through the disposal of their non-water assets. ${ }^{52}$

\section{Operation Feed Nation (OFN)}

This programme was established on $21^{\text {st }}$ May, 1976 under the administration of General Olusegun Obasanjo. The programme similar to other programme was to tackle the high food insecurity, food prices and curb rural-urban migration in Nigeria. The Operation Feed Nation was initiated the improved food shortages that had taken ride of the nation. ${ }^{53}$ The programme would employ the services all the citizens of the country irrespective of the profession. The slogan was "any profession, farm." 54

Through the program, the Nigerian military government also promised to make farm inputs such as fertilizers and simple equipment such as hoes, machetes and cutlasses available at highly subsidized prices to farmers. ${ }^{55}$ Under the programme every available piece of land in urban, sub-urban and rural areas was meant to be planted. ${ }^{56}$ It was a "wild life dream" for the military government to tackle the food crisis of the nation through involving all citizens of the country regardless of one's experience in farming. 
Though the programme was massively expected to alleviate the society from food scourge with its objectives petered off before it even attained its noon. The loan, agricultural items and equipment meant to assist the peasant, farmers and ordinary people in rural areas were pocketed by the government officials. The citizens only saw the government assistance on television and radio. ${ }^{57}$ Operation Feed Nation was an 'invisible programme, it was only seen in daily newspapers and national news.' 58 The claimed "direct benefit to the farmer" that government chanted in praise of the program remained, to all intents and purpose mere populist sloganeering. ${ }^{59}$ Okoye, a settler in Igbariam analyzing the OFN as its affects the settlement concludes that:

OFN was a wolf in sheep clothing. At the inception of the programme in Nigeria, we were happy that it would revive the settlement and assist the poor farmers with equipment and loans... but by the end of 1977 , the programme was a shadow. ${ }^{60}$

It is a truism that the Federal Government of Nigeria since the end of the civil war had promoted various agricultural programmes and policies in order to promote the bedeviling economy of the nation against the abrogated scheme previous in Eastern Nigeria. These programmes had faced one challenge or the other which had no doubt crippled the Gross Domestic Product and standard of living of the nation. Thus, the colonial and post-independence agricultural policies seems to be an increasing economy to Nigeria than the postcivil war leaders who saw agriculture as mere sector. Decline in agricultural production, especially viz-a-vis fast expanding population, triggered ever increasing food import bills: £21.9 million ( $\$ 43.8$ million) in 1963 , 526.7 million in 1970 and $¥ 368.4$ billion in 2011. ${ }^{61}$ Nigeria's exports of good and services as percentage of GDP is $13.17 \%$ and imports of goods of goods and services as percentage of GDP is $13.18 \%$ as of October $2019 .{ }^{62}$

\begin{tabular}{|l|l|l|l|}
\hline Commodity & Total Import (Abillion) & $\begin{array}{l}\text { Average Import/yr. } \\
(\text { Pbillion) }\end{array}$ & Ranking \\
\hline Wheat & 823.84 & 164.77 & $1^{\text {st }}$ \\
\hline Prepared Cereals & 159.60 & 31.92 & $6^{\text {th }}$ \\
\hline Fish & 568.17 & 113.63 & $2^{\text {nd }}$ \\
\hline Milk/Dairy & 312.57 & 62.51 & $3^{\text {rd }}$ \\
\hline Sugar & 193.07 & 38.61 & $5^{\text {th }}$ \\
\hline Rice & & 54.24 & $4^{\text {th }}$ \\
\hline Cocoa & 271.19 & 0.66 & $8^{\text {th }}$ \\
\hline Oils & & 20.96 & $9^{\text {th }}$ \\
\hline Oil seeds & 3.31 & 5.10 & \\
\hline
\end{tabular}




\begin{tabular}{|l|l|l|l|}
\hline Prepared Vegetables and & 111.98 & 22.40 & $7^{\text {th }}$ \\
Fruits & & & \\
\hline
\end{tabular}

V. Olusoji, et al, “An Analysis of Nigeria Food Imports and Bills", 6.

The post-independence leaders were farsighted in building a resounding economy through promoting indigenous agricultural sector such as establishment of farm settlement while post-civil war leaders deepened their ideas in oil sector and importation of food items. The situation is worse when food commodities which a nation has comparative advantage for their production are being imported. ${ }^{63}$ The agricultural programmes initiated after the civil war have proven worse than what was obtainable before the war. This economy has not only affected the Igbo society that was devastated during the war but had ridiculed the development and advancement of the nation's economy.

\section{End Notes}

1. C. Onyema, "Biafra, War, Historic Burden and Artistic Vision" in C.J. Korieh and I. Ezeonu (eds), Remembering Biafra: Narrative History and Memory of the Nigeria-Biafra War, (New Jersey: Goldline and Jacobs Publishing, 2015), 95.

2. N.A. Obi-Ani, "The Nigeria-Biafra War and the Occupation of Nsukka and Enugu Areas of Biafra, 1967-1979", Ph.D Dissertation submitted to the Department of History and International Studies, Nnamdi Azikiwe University, Awka, 166.

3. Obi-Ani, "The Nigeria-Biafra War and the Occupation of Nsukka and Enugu Areas of Biafra, 1967-1979”, 166.

4. P. Obi-Ani, Post Civil War Political and Economic Reconstruction of Igboland, 1979-1983, (Nsukka: Great Ap Express, 2009), 15.

5. Obi-Ani, Post Civil War Political and Economic Reconstruction of Igboland, 1979-1983, 15.

6. F. Forsyth, The Making of an African Legend: The Biafra Story. (New York: Penguin Books, 1977)

7. E. Okoye, 1933, Settler, interviewed at Igbariam, 5 January, 2019.

8. Obi-Ani, "The Nigeria-Biafra War and the Occupation of Nsukka and Enugu Areas of Biafra, 1967-1979”, 166.

9. C.J. Korieh, The Land Has Changed: History, Society and Gender in Colonial Eastern Nigeria. (Alberta: University of Calgary Press, 2010), 229.

10. Okoye, interview cited.

11. C.U. Osakwe, 1952, Settler, interviewed at Igbariam, 7 January, 2019.

12. Obi-Ani, "The Nigeria-Biafra War and the Occupation of Nsukka and Enugu Areas of Biafra, 1967-1979", 168.

13. Obi-Ani, Post Civil War Political and Economic Reconstruction of Igboland, 1979-1983, 15.

14. O. Iwuagwu, "Colonial and Post-Independence Agricultural Policies in Eastern Nigeria, 1946 - 1980", www.research gate.net/publication/272338619. Accessed 4/9/2018.

15. Obi-Ani, Post Civil War Political and Economic Reconstruction of Igboland, 35.

16. Obi-Ani, Post Civil War Political and Economic Reconstruction of Igboland, 57.

17. Obi-Ani, Post Civil War Political and Economic Reconstruction of Igboland, 36.

18. Obi-Ani, Post Civil War Political and Economic Reconstruction of Igboland, 57. 
19. W. West, The Tribune, 15 April, 1966 in C. Okoro, "The Uzo-Uwani Farm Settlement and Socio-Economic Development in the Anambra Basin, 1961-1971, MA Thesis, University of Nigeria, Nsukka, 1986, 48-49.

20. Intelligent Report on Farm Settlement, MANR 1/1/547, AMAS 1991 III, 813.

21. Intelligent Report on Farm Settlement, 823.

22. Intelligent Report on Farm Settlement, 823.

23. Intelligent Report on Farm Settlement, 9.

24. Intelligent Report on Farm Settlement, 923.

25. Okoye, interviewed cited.

26. Osaekwe, interviewed cited.

27. Okoye, interviewed cited.

28. Obi-Ani, Post Civil War Political and Economic Reconstruction of Igboland, 58.

29. Intelligent Report on Integrated Mechanised Farming, MANR 1/1/438, AMAS 147, 2-3.

30. Intelligent Report on Integrated Mechanised Farming, 8-9.

31. Federal Economic Mission to East Central State, 1972-1979, MANR 1/1/448, AMAS 156/S.1, 17.

32. Federal Economic Mission to East Central State, 1972-1979, 68.

33. Federal Economic Mission to East Central State, 1972-1979, 68.

34. M. Achumi, 1943, Settler, interviewed at Igbariam, 7 January, 2019.

35. A. Oraukwu, 1969, Settler, interviewed at Igbariam, 7 January, 2019.

36. E.G. Okafor, 1952, Settler, interviewed at Igbariam, 7 January, 2019.

37. O. Njoku, c.78, Retired University Teacher, interviewed at University of Nigeria, Nsukka, 3 October, 2019

38. Money Is Not Our Problem, But How To Spend It - Gowon - Politics - Nigeria-Naira land, Naira land Forum. http://allafrica.com/stories/201410202349.html. Accessed 03/09/2018.

39. Iwuagwu, "Colonial and Post-Independence Agricultural Policies in Eastern Nigeria, 1946 - 1980", 10.

40. Obi-Ani, Post Civil War Political and Economic Reconstruction of Igboland, 59.

41. Iwuagwu, "Colonial and Post-Independence Agricultural Policies in Eastern Nigeria, 1946 - 1980”, 10.

42. O. Njoku, Economic History of Nigeria, $19^{\text {th }}-21^{\text {st }}$ Centuries, Nsukka: Great AP Publishers, 2014, 313.

43. Njoku, Economic History of Nigeria, $19^{\text {th }}-21^{s t}$ Centuries, 313.

44. Njoku, Economic History of Nigeria, $19^{\text {th }}-21^{\text {st }}$ Centuries, 314.

45. J.C. Iwuchukwu and E.M. Igbokwe, "Lessons from Agricultural Policies and Programmes in Nigeria", Journal of Law, Policy and Globalization, 5 (2012), 13.

46. Iwuchukwu and Igbokwe, "Lessons from Agricultural Policies and Programmes in Nigeria", 13.

47. Njoku, Economic History of Nigeria, $19^{\text {th }}-21^{\text {st }}$ Centuries, 315.

48. Njoku, Economic History of Nigeria, $19^{\text {th }}-21^{\text {st }}$ Centuries, 316.

49. Njoku, Economic History of Nigeria, $19^{\text {th }}-21^{\text {st }}$ Centuries, 316.

50. Njoku, Economic History of Nigeria, $19^{\text {th }}-21^{\text {st }}$ Centuries, 316.

51. Njoku, Economic History of Nigeria, $19^{\text {th }}-21^{\text {st }}$ Centuries, 319.

52. Iwuchukwu and Igbokwe, "Lessons from Agricultural Policies and Programmes in Nigeria", 14.

53. A. Isiani, 1953, Retired Civil Servant, interviewed at Onitsha, 25 May, 2019.

54. Isiani, interview cited. 
International Journal of Scientific and Research Publications, Volume 10, Issue 2, February 2020

55. Njoku, Economic History of Nigeria, $19^{\text {th }}-21^{\text {st }}$ Centuries, 321.

56. Iwuchukwu and Igbokwe, "Lessons from Agricultural Policies and Programmes in Nigeria", 13.

57. Isiani, interview cited.

58. U. Okonkwo, 1976, Civil Servant, interviewed at University of Nigeria, Nsukka, 28 October, 2019.

59. Njoku, Economic History of Nigeria, $19^{\text {th }}-21^{\text {st }}$ Centuries, 322.

60. Okoye, interview cited.

61. Njoku, Economic History of Nigeria, $19^{\text {th }}-21^{\text {st }}$ Centuries, 336.

62. Nigeria Trade Statistics: Exports, Imports, Products, Tariffs, GDP and related Development Indicator. https://wits.worldbank.org/country. Accessed 29 October, 2019.

63. V.I. Olusoji, A.C. Afolake, O.T. Olayemi, and A.A. Oladipo "An Analysis of Nigeria Food Imports and Bills", International Journal of Economics, Commerce and Management, Vol. II, Issue 9, (2014), 1. 